\title{
Characterization of the Interleukin-28B Gene rs 12979860 C/T Polymorphism in Turkish Chronic Hepatitis C Patients and Healthy Individuals
}

\author{
Serpil Taheri ${ }^{1,3}$, Bilgehan Aygen², Keziban Korkmaz ${ }^{3}$, Orhan Y1ldız ${ }^{4}$, Gökmen Zararsız ${ }^{5}$, Halit Canatan ${ }^{1}$ \\ ${ }^{1}$ Department of Medical Biology, Erciyes University Faculty of Medicine, Kayseri, Turkey \\ ${ }^{2}$ Department of Infectious Diseases and Clinical Microbiology, Erciyes University Faculty of Medicine, Kayseri, Turkey \\ ${ }^{3}$ Betül-Ziya Eren Genome and Stem Cell Center, Erciyes University, Kayseri, Turkey \\ ${ }^{4}$ Department of Infectious Diseases and Clinical Microbiology, Erciyes University Faculty of Medicine, Kayseri, Turkey \\ ${ }^{5}$ Department of Biostatistics, Erciyes University Faculty of Medicine, Kayseri, Turkey
}

Background: Host genetic factors can affect the progress of hepatitis-C virus (HCV) infection. Interleukin28B (IL28B) single nucleotide polymorphisms may play an important role in the clearance of HCV spontaneously or with treatment.

Aims: The aim of our study was to evaluate the rate of IL28B genotypes in patients with Chronic Hepatitis-C (CHC) and healthy control subjects and to examine the characteristics of patients in each IL28B subgroup.

Study Design: Case-control study.

Methods: IL28B polymorphisms were genotyped by Polymerase Chain Reaction and Restriction Fragment Length Polymorphism (PCR-RFLP) in all subjects.

Results: The mean age was $52.3 \pm 10.9$ years $(33 \%$ female) in the CHC patients and $52.5 \pm 11.5$ years $(39.1 \%$ female) in the healthy controls. The percentage of patients with a high baseline viral load $(\geq 400,000 \mathrm{IU} / \mathrm{mL})$ was higher in the CT group (69.8\%) compared to the
$\mathrm{C} / \mathrm{C}(44.4 \%)$ and $\mathrm{T} / \mathrm{T}(50 \%)$ groups $(\mathrm{p}=0.021)$. There was no significant difference in liver fibrosis and liver necroinflammation distribution among the $\mathrm{CC}, \mathrm{CT}$ and TT genotypes with mild, moderate and severe groups $(p=0.058$ and $p=0.791$, respectively). Mean age, gender ratio, body mass index, viral load at baseline, rate of HCV genotypes, baseline ALT levels were not significantly different among the three IL28B subgroups $(p>0.05)$. A significant increase was observed in the frequencies of IL28B rs12979860 TT genotypes in the CHC patients (20.6\%) compared to the healthy control group $(8.7 \%)(\mathrm{p}=0.033)$.

Conclusion: In the patients with chronic HCV-genotype $1 \mathrm{~b}$ and 4 infections, the IL28B rs12979860 (C>T) gene polymorphism frequency of the TT genotype and T allele was higher than in healthy control subjects. This result indicates that the TT genotype may be more effective in the progression of HCV infection than other genotypes.

Keywords: Chronic hepatitis C, gene polymorphism, IL28B, interleukins

This study was presented at the $24^{\text {th }}$ Conference of the Asian Pacific Association for the Study of the Liver, 12-15 March 2014, Brisbane, Australia.

Address for Correspondence: Dr. Serpil Taheri, Betül-Ziya Eren Genome and Stem Cell Center, Kayseri, Turkey

Phone: +905333252342 e-mail: serpiltaheri@hotmail.com

Received: 24.05.2014 Accepted: 10.12.2014 • DOI: 10.5152/balkanmedj.2015.15156

Available at www.balkanmedicaljournal.org

Cite this article as:

Taheri S, Aygen B, Korkmaz K, Yildiz O, Zararsiz G, Canatan H. Characterization of the interleukin-28B gene rs12979860 C/T polymorphism in Turkish chronic

hepatitis $\mathrm{C}$ patients and healthy individuals.

Balkan Med J 2015;32:147-55. 
The hepatitis-C virus (HCV) is an important global health problem. HCV causes chronic liver disease, leading to complications such as liver cancer and cirrhosis (1-4). In Turkey, the prevalence of $\mathrm{HCV}$ between 2000 and 2006 was $0.54 \%$ $(0.2-5.2 \%)$ in $1,076,495$ blood donors (5). In addition, the contribution of $\mathrm{HCV}$ to chronic hepatitis etiology increased from $23 \%$ to $38.1 \%$ and its contribution to cirrhosis increased from $25.2 \%$ to $45.9 \%$ in the last 10 years (6). The most common HCV genotype in Turkey is genotype 1b, which occurs in $68-94 \%$ of the population (7), although there has been a recent increase in genotype 4 infections (8). Unfortunately, HCV treatment is difficult and the possibility of a sustained virological response (SVR) through treatment is low in chronic hepatitis-C (CHC) caused by these genotypes. Thus, when the frequency of $\mathrm{HCV}$ infection, common genotype and high cost of CHC treatment are taken into consideration, it is clear that patient treatments should be chosen carefully.

There are many factors affecting the progression of $\mathrm{HCV}$ infection and its response to treatment in chronic cases (9-12). In multiple Genome Wide Association Studies (GWAS), a single nucleotide polymorphism (SNP) of the IL28B gene 3-kb upstream ( $r s 12979860 \mathrm{C}>\mathrm{T}$ ), encoded by Interferon-13 (IFN-13), had a substantial role in the disappearance of $\mathrm{HCV}$ infection spontaneously or with treatment (13). Recent studies have determined that IL28B rs12979860 is the primary factor contributing to healing from infection (14-16), increasing response to treatment by almost two-fold $(17,18)$. Moreover, the rates of SVR change based on genetic polymorphism in the IL28B gene, which is low in African Americans and Caucasians but high in Asian populations (19). Furthermore, the IL28B genotype is a very strong predictor for SVR in treatment protocols that include a protease inhibitor or in Interferon (IFN) plus ribavirin combination treatments $(20,21)$.

The aim of this study was to investigate the relationship between the IL28B rs12979860 (C>T) polymorphism in Turkish patients with chronic-HCV genotype- $1 \mathrm{~b}$ and 4 infections and healthy control subjects, and to analyze the characteristics of the patients in each IL28B subgroup.

\section{MATERIALS AND METHODS}

\section{Patients and healthy subjects}

This study was conducted with 136 patients diagnosed with CHC (45 female and 91 male) and a control group of 92 healthy individuals ( 36 female and 56 male). The patients were monitored in the Infectious Diseases Outpatient Clinic from 2010 to 2013 years. The mean age was $52.3 \pm 10.9$ years (age range 19-70). CHC was diagnosed in cases with com- pensated disease through liver biopsy, normal or high liver enzymes, anti-HCV antibodies and positive HCV RNA. We excluded patients who had other chronic liver diseases, positive hepatitis B surface antigen (HBsAg) and human immunodeficiency virus (HIV). The liver biopsies taken percutaneously were evaluated using the Ishak scoring system (22), which categorizes fibrosis with a score of $0-2$ as mild, 3-4 as moderate and 5-6 as severe (23). Subjects in the healthy control group had a mean age of $52.5 \pm 11.5$ years (age range 18-70) and none had any hepatic disease (i.e., infection, long term drug use, autoimmune-hepatitis or alcohol consumption) or endocrine disease and the results of their liver function tests and liver ultrasonography were normal.

For all patients, demographics, body mass indices (BMI), alanine aminotransferase (ALT) HCV RNA levels, viral genotypes were recorded on private forms designed for the study, liver biopsy necroinflammation and fibrosis results were evaluated based on the Ishak scoring system Liver biopsy was performed in 109/136 patients. All subjects provided written informed consent for genetic analysis. The study was approved by the Ethics Committee for Clinical Research, which conforms to protocols in accordance with the Declaration of Helsinki (Decision number: 2013-188).

\section{Blood samples and laboratory tests}

Routine biochemical tests were performed from venous blood samples with an automated device and HBsAg, anti$\mathrm{HCV}$, and-HIV antibodies examined via an enzyme immunoassay method (anti-HCV and anti-HIV: Architect System, Abbott Diagnostics, Germany; HBsAg: Roche Diagnostics, USA). Quantitative HCV RNA levels were performed using real-time polymerase chain reaction (PCR, COBAS Ampliprep/COBAS TaqMan 48, Roche Molecular Systems, USA) and the HCV genotype was determined through pyrosequencing according to the directions of the manufacturer (Qiagen, Hilden, Germany). Blood samples were taken into vacutainer tubes containing Ethylene Diamine Tetraacetic Acid (EDTA).

\section{IL-28B rs12979860 (C $>$ T) Polymorphism Detection}

Genotyping of the IL-28B rs12979860 (C>T) polymorphism was performed by a PCR-RFLP method. DNA was extracted from whole blood samples using the DNA blood mini kit (Qiagen, Milan, Italy). After DNA isolation, DNA samples were stored at $-80^{\circ} \mathrm{C}$.

Using genomic DNA samples, a 139 base pair (bp) product was amplified with the following primers: forward primer, IL28BF 5'-CCAGGGCCCCTAACCTCTGCA-3'; reverse primer, IL28BR 5'-GGGAGCGCGGAGTGCAATTCA-3. Amplification was carried out in a total volume of $50 \mu \mathrm{L}$ 
containing $10 \mathrm{mmol} / \mathrm{L}$ Tris- $\mathrm{HCl}(\mathrm{pH} 8.3), 50 \mathrm{mmol} / \mathrm{L} \mathrm{KCl}$, Tween-20 $0.01 \%, 0.2 \mathrm{mmol} / \mathrm{L}$ deoxyribonucleotides, $2-5$ pmol of each primer, $2.0 \mathrm{mmol} / \mathrm{L} \mathrm{MgCl}, 0.5$ units Taq DNA polymerase (Thermo Taq, Pittsburgh PA, USA) and $\sim 10 \mathrm{ng}$ genomic DNA. The thermal protocol for amplification included 36 cycles of denaturation at $94^{\circ} \mathrm{C}$ for $60 \mathrm{~s}$, annealing at $62^{\circ} \mathrm{C}$ for $50 \mathrm{~s}$, and elongation at $72^{\circ} \mathrm{C}$ for $60 \mathrm{~s}$. The PCR products were digested with 1 unit $B s t U I$ (New England Biolabs, Hitchin, UK) in a total volume of $25 \mu \mathrm{L}$ at $37^{\circ} \mathrm{C}$ for six hours. The fragments were resolved by electrophoresis in a $3 \%$ agarose gel, followed by staining with ethidium bromide. A band of $139 \mathrm{bp}$ indicates the TT genotype, $109 \mathrm{bp}$ indicates the CC genotype, and two bands (139 and $109 \mathrm{bp}$ ) indicate the CT genotype (24).

\section{Statistical analysis}

To assess data normality, histogram and q-q plots were plotted and data analyzed using the Shapiro-Wilk test. The Levene test was used to assess variance homogeneity. For baseline viral load variables, a logarithmic transformation was applied to account for a highly skewed distribution. To compare the differences between groups, independent samples t test, MannWhitney $U$ test, one-way analysis of variance, Kruskal-Wallis test and Pearson's $\chi^{2}$ analysis were used. Multiple comparisons were made using 2 -sample chi-square test for equality of proportions with continuity correction. Data were expressed as frequencies and percentages, means and standard deviations, geometric means and $95 \%$ confidence intervals, or medians and interquartile ranges. Analysis was performed using the $\mathrm{R}$ 3.0.1 software (www.r-project.org) and a value of $p<0.05$ was taken to indicate statistical significance. $\mathrm{R}$ is an open source and free software environment for statistical computing and graphics. It includes more than 5.000 statistical packages in CRAN network, also has about 1.000 packages in BIOCONDUCTOR network for bioinformatics analysis. $R$ can be assessed from www.r-project.org.

\section{RESULTS}

\section{Patient and healthy control demographics}

The demographic characteristics of $136 \mathrm{CHC}$ patients and 92 healthy controls are shown in Table 1 . The mean BMI was $26.3 \pm 4.0 \mathrm{~kg} / \mathrm{m}^{2}$ in the CHC patients and $26.5 \pm 5.9 \mathrm{~kg} / \mathrm{m}^{2}$ in the healthy controls. Based on the BMI, 39\% of the CHC patients were normal weight, $47.8 \%$ were overweight and $13.2 \%$ were obese. In the control group, $35 \%$ were of normal weight, $52 \%$ were overweight, and $13 \%$ were obese. There was no significant difference in mean age, gender distribution or BMI between the control and patient groups ( $p>0.05)$.

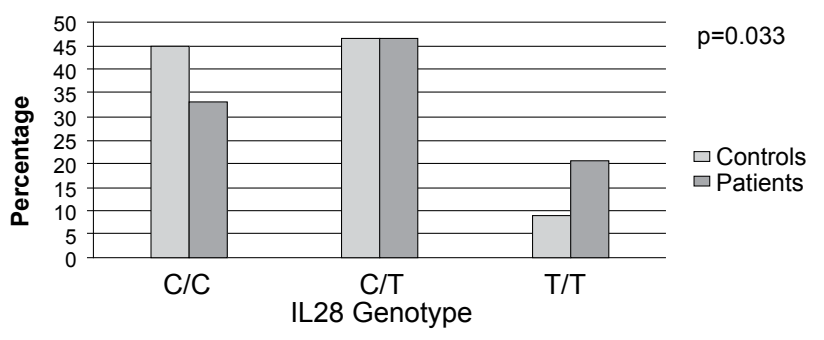

FIG. 1. IL28B rs12979860 C/T polymorphism in control and in patients with chronic $\mathrm{HCV}$ infection

The mean HCV RNA level of the CHC patients was 307,094 $\mathrm{IU} / \mathrm{mL}$. For $55.1 \%$ of the patients, viral load was $\geq 400,000$ $\mathrm{IU} / \mathrm{mL}$ and $90.4 \%$ were infected with genotype $1 \mathrm{~b}$. The mean ALT level was $48 \mathrm{IU} / \mathrm{L}$. A liver biopsy was carried out in 109 patients. The severity of liver fibrosis was mild for $63.2 \%$ of the patients, moderate for $14.7 \%$ and severe for $2.2 \%$. The distribution of liver necroinflammation was found as $62.5 \%$ for mild, $16.9 \%$ for moderate and $0.7 \%$ for severe.

\section{IL28B genotypes}

When the IL28B genotype was assessed in patients with $\mathrm{CHC}$, the CC genotype was identified in $32.1 \%$, the CT genotype in $46.3 \%$ and the TT genotype in $20.6 \%$. In the control group, the CC genotype was identified in $44.6 \%$, the CT genotype in $46.7 \%$, and the TT genotype in $8.7 \%$. There was a significant difference in genotype distribution between the patient and control groups ( $p=0.033$; Figure 1). Based on the multiple comparisons, the significance occurred between the frequency differences of the CC and TT genotypes $(\mathrm{p}=0.016)$. The frequency of the TT genotype was higher in the CHC patient group compared to the control group. Moreover, patients with the CT genotype had 1.33-fold and those with TT had 3.19-fold increased risk of HCV infection when compared to patients with the CC genotype (Table 2).

In the patient group, the $\mathrm{C}$ allele frequency was $0.56(56 \%)$ and $\mathrm{T}$ allele frequency was $0.44(44 \%)$, while in the control group, the $\mathrm{C}$ allele frequency was $0.68(68 \%)$ and the $\mathrm{T}$ allele frequency was $0.32(32 \%)$; this resulted in a significant difference in the frequencies of $\mathrm{C}$ and $\mathrm{T}$ alleles between the groups ( $\mathrm{p}=0.011$ ). We found that patients with the $\mathrm{T}$ allele had a 1.67-fold increased risk of chronic HCV infection compared to those with the $\mathrm{C}$ allele (Table 2).

\section{Characteristics of the CHC patients based on the IL28B genotype}

The characteristics of the CHC patients based on the IL28B genotype subgroups are summarized in Table 3 . The geometric mean baseline HCV RNA levels were $209,779 \mathrm{IU} / \mathrm{mL}$ in the CC group, $397,049 \mathrm{IU} / \mathrm{mL}$ in the $\mathrm{CT}$ group and 317,854 
TABLE 1. The characteristics of Chronic Hepatitis-C patients and healthy control group

\begin{tabular}{|c|c|c|c|c|c|}
\hline Variable & Chronic HCV (n=136) & Control subjects $(\mathrm{n}=92)$ & Test Statistic & $\mathrm{p}$ & OR $(95 \% \mathrm{CI})$ \\
\hline \multicolumn{6}{|l|}{ Gender, n (\%) } \\
\hline Female & $45(33.0)$ & $36(39.1)$ & $\chi^{2}=0.875$ & 0.350 & 1.00 \\
\hline Male & $91(67.0)$ & $56(60.9)$ & & & $1.30(0.75-2.27)$ \\
\hline Age (years), mean \pm SD & $52.3 \pm 10.9$ & $52.5 \pm 11.5$ & $\mathrm{t}=0.084$ & 0.933 & $1.00(0.98-1.02)$ \\
\hline BMI $\left(\mathrm{kg} / \mathrm{m}^{2}\right)$, mean $\pm \mathrm{SD}$ & $26.3 \pm 4.0$ & $26.5 \pm 5.9$ & & & $0.99(0.94-1.05)$ \\
\hline Normal weight $\left(<25 \mathrm{~kg} / \mathrm{m}^{2}\right), \mathrm{n}(\%)$ & $53(39.0)$ & $32(35.0)$ & & & 1.00 \\
\hline Overweight (25-29.9 kg/m²), n (\%) & $65(47.8)$ & $48(52.0)$ & $\mathrm{t}=0.259$ & 0.796 & $0.82(0.46-1.45)$ \\
\hline Obese $\left(\geq 30 \mathrm{~kg} / \mathrm{m}^{2}\right), \mathrm{n}(\%)$ & $18(13.2)$ & $12(13.0)$ & $\chi^{2}=0.472$ & 0.790 & $0.91(0.39-2.12$ \\
\hline $\begin{array}{l}\text { Viral load at baseline }(\mathrm{IU} / \mathrm{mL}) \\
\text { geometric mean }(95 \% \mathrm{CI})^{\mathrm{a}}\end{array}$ & $\begin{array}{c}307.094 \\
(193.524-506.006)\end{array}$ & & & & \\
\hline$<400,000 \mathrm{IU} / \mathrm{mL}, \mathrm{n}(\%)$ & $61(44.9)$ & & & & \\
\hline$\geq 400,000 \mathrm{IU} / \mathrm{mL}, \mathrm{n}(\%)$ & $75(55.1)$ & & & & \\
\hline \multicolumn{6}{|l|}{ Genotype, n (\%) } \\
\hline Genotype $1 \mathrm{~b}$ & $123(90.4)$ & & & & \\
\hline Genotype 4 & $13(9.6)$ & & & & \\
\hline $\begin{array}{l}\text { Baseline ALT level (IU/L), median } \\
\left(1^{\text {st }}-3^{\text {rd }} \text { quartiles }\right)\end{array}$ & $48(26.2-59.0)$ & & & & \\
\hline \multicolumn{6}{|c|}{ Distribution of liver necroinflammation ${ }^{\mathrm{b}}, \mathrm{n}(\%)$} \\
\hline Mild & $85(62.5)$ & & & & \\
\hline Moderate & $23(16.9)$ & & & & \\
\hline Severe & $1(0.7)$ & & & & \\
\hline \multicolumn{6}{|l|}{ Distribution of liver fibrosis ${ }^{\mathrm{b}}, \mathrm{n}(\%)$} \\
\hline Mild & $86(63.2)$ & & & & \\
\hline Moderate & $20(14.7)$ & & & & \\
\hline Severe & $3(2.2)$ & & & & \\
\hline
\end{tabular}

BMI: body mass index; ALT: alanin aminotransferase; SD: standard deviation; OR: odds ratio; CI: confidence interval.

The tests applied are independent samples $t$ test where mean $\pm \mathrm{SD}$ is given and Pearson's chi-square test where $\mathrm{n}(\%)$ is given.

$\mathrm{OR}=1$ corresponds to reference category.

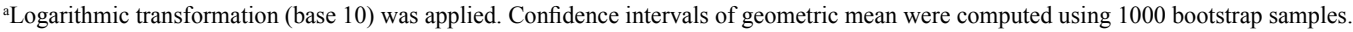

${ }^{\mathrm{b}} 109$ patients with liver biopsy were evaluated according to the Ishak score.

TABLE 2. Allele and genotype frequencies of IL28B rs12979860 (C>T) polymorphism in control and patients with chronic HCV infections

\begin{tabular}{|c|c|c|c|c|c|}
\hline IL28B & $\begin{array}{c}\text { Chronic HCV } \\
\text { infection }(n=136)\end{array}$ & $\begin{array}{c}\text { Control subjects } \\
\qquad(\mathrm{n}=92)\end{array}$ & Test Statistic & $\mathrm{p}$ & OR $(95 \% \mathrm{CI})$ \\
\hline rs12979860 allele frequency & $\begin{array}{l}\mathrm{C}=0.56 \\
\mathrm{~T}=0.44\end{array}$ & $\begin{array}{l}\mathrm{C}=0.68 \\
\mathrm{~T}=0.32\end{array}$ & $\chi^{2}=6.686$ & 0.011 & $\begin{array}{c}1.00 \\
1.67(1.14-2.50)\end{array}$ \\
\hline rs 12979860 & $\begin{array}{l}\mathrm{CC}=45(32.1) \\
\mathrm{CT}=63(46.3) \\
\mathrm{TT}=28(20.6)\end{array}$ & $\begin{array}{c}\mathrm{CC}=41(44.6) \\
\mathrm{CT}=43(46.7) \\
\mathrm{TT}=8(8.7)\end{array}$ & $\chi^{2}=6.834$ & 0.033 & $\begin{array}{c}1.00 \\
1.33(1.10-1.51) \\
3.19(2.87-3.49)\end{array}$ \\
\hline \multicolumn{6}{|l|}{ Pairwise comparisons } \\
\hline $\mathrm{CC}$ and $\mathrm{CT}$ & - & - & $\chi^{2}=0.707$ & 0.400 & - \\
\hline $\mathrm{CC}$ and $\mathrm{TT}$ & - & - & $\chi^{2}=5.823$ & 0.016 & - \\
\hline $\mathrm{CT}$ and TT & - & - & $\chi^{2}=3.172$ & 0.075 & - \\
\hline
\end{tabular}

OR: odds ratio; CI: confidence interval. The tests applied are Pearson's chi-square test. Post-hoc tests are applied using 2-sample chi-square test for equality of proportions with continuity correction. $\mathrm{OR}=1$ corresponds to reference category.

$\mathrm{IU} / \mathrm{mL}$ in the TT group. The frequency of patients with a viral load $\geq 400,000 \mathrm{IU} / \mathrm{mL}$ was significant among patients with different genotypes $(\mathrm{p}=0.021)$. Based on multiple com- parisons, the frequency in patients with the $\mathrm{CC}$ genotype was found to be lower than in patients with the CT genotype $(\mathrm{p}=0.014)$. 
TABLE 3. Patients characteristics in each IL28B genotype subgroup

\begin{tabular}{|c|c|c|c|c|c|c|c|c|}
\hline \multirow[b]{2}{*}{ Variables } & \multicolumn{3}{|c|}{ Genotypes } & \multirow[b]{2}{*}{$\begin{array}{c}\text { Test } \\
\text { Statistic }\end{array}$} & \multirow[b]{2}{*}{$\mathrm{p}$} & \multicolumn{3}{|c|}{ Pairwise Comparisons } \\
\hline & $\begin{array}{c}\mathrm{C} / \mathrm{C} \\
(\mathrm{n}=45)\end{array}$ & $\begin{array}{c}\mathrm{C} / \mathrm{T} \\
(\mathrm{n}=63)\end{array}$ & $\begin{array}{c}\mathrm{T} / \mathrm{T} \\
(\mathrm{n}=28)\end{array}$ & & & $\begin{array}{l}\mathrm{C} / \mathrm{C} \text { and } \\
\mathrm{C} / \mathrm{T}\end{array}$ & $\begin{array}{l}\mathrm{C} / \mathrm{C} \text { and } \\
\mathrm{T} / \mathrm{T}\end{array}$ & $\begin{array}{c}\mathrm{C} / \mathrm{T} \text { and } \\
\mathrm{T} / \mathrm{T}\end{array}$ \\
\hline Age (years), mean $\pm \mathrm{SD}$ & $51.4 \pm 12.5$ & $53.1 \pm 10.3$ & $52.3 \pm 9.6$ & $\mathrm{~F}=0.304$ & 0.738 & - & - & - \\
\hline Male, n (\%) & $28(62.2)$ & $45(71.4)$ & $18(64.3)$ & $\chi^{2}=1.115$ & 0.573 & - & - & - \\
\hline BMI $\left(\mathrm{kg} / \mathrm{m}^{2}\right)$, mean $\pm \mathrm{SD}$ & $26.4 \pm 4.1$ & $26.6 \pm 4.1$ & $25.5 \pm 3.6$ & $\mathrm{~F}=0.913$ & 0.476 & & & \\
\hline $\begin{array}{l}\text { Viral load at baseline }(\mathrm{IU} / \mathrm{mL}) \text { geometric mean } \\
(95 \% \mathrm{CI})^{\mathrm{a}}\end{array}$ & $\begin{array}{l}209.779 \\
(79.943- \\
542.676)\end{array}$ & $\begin{array}{c}397.049 \\
(206.916- \\
728.103)\end{array}$ & $\begin{array}{c}317.854 \\
(96.161- \\
861.159)\end{array}$ & $\mathrm{F}=0.646$ & 0.526 & - & - & - \\
\hline Viral load $\geq 400,000 \mathrm{IU} / \mathrm{mL}, \mathrm{n}(\%)$ & $20(44.4)$ & $44(69.8)$ & $14(50.0)$ & $\chi^{2}=7.702$ & 0.021 & $\begin{array}{l}\chi^{2}=6.00 \\
p=0.014\end{array}$ & $\begin{array}{l}\chi^{2}=0.05 \\
\mathrm{p}=0.825\end{array}$ & $\begin{aligned} \chi^{2} & =2.50, \\
\mathrm{p} & =0.114\end{aligned}$ \\
\hline Genotype $1 \mathrm{~b}, \mathrm{n}(\%)$ & $43(36.6)$ & $55(44.7)$ & $25(20.3)$ & $\chi^{2}=0.654$ & 0.721 & - & - & - \\
\hline Genotype 4, n (\%) & $3(6.7)$ & $7(11.1)$ & $3(10.7)$ & & & & & \\
\hline $\begin{array}{l}\text { Baseline ALT level (IU/L), median ( } 1^{\text {st }-3^{\text {rd }}} \\
\text { quartiles) }\end{array}$ & $\begin{array}{c}39.0 \\
(26.0-53.0)\end{array}$ & $\begin{array}{c}48.0 \\
(27.0-59.0)\end{array}$ & $\begin{array}{c}57.0 \\
(29.5-75.0)\end{array}$ & $\chi^{2}=3.121$ & 0.210 & - & - & - \\
\hline \multicolumn{9}{|l|}{ Distribution of liver necroinflammation ${ }^{\mathrm{b}}, \mathrm{n}(\%)$} \\
\hline Mild (1-6) & $28(82.4)$ & $40(76.9)$ & $17(73.9)$ & $\chi^{2}=1.699$ & 0.791 & - & - & - \\
\hline Moderate (7-12) & $6(17.6)$ & $11(21.2)$ & $6(26.1)$ & & & & & \\
\hline Severe (13-18) & $0(0.0)$ & $1(1.9)$ & $0(0.0)$ & & & & & \\
\hline \multicolumn{9}{|l|}{ Distribution of liver fibrosis ${ }^{\mathrm{b}}, \mathrm{n}(\%)$} \\
\hline Mild (0-2) & $31(91.2)$ & $35(67.3)$ & $20(87.0)$ & $\chi^{2}=9.130$ & 0.058 & - & - & - \\
\hline Moderate (3-4) & $3(8.8)$ & $14(26.9)$ & $3(13.0)$ & & & & & \\
\hline Severe (5-6) & $0(0.0)$ & $3(5.8)$ & $0(0.0)$ & & & & & \\
\hline
\end{tabular}

BMI: body mass index; ALT: alanin aminotransferase; SD: standard deviation; CI: confidence interval.

The tests applied are one-way analysis of variance where mean \pm SD or geometric mean $(95 \% \mathrm{CI})$ is given, Kruskal-Wallis $\mathrm{H}$ test where median $\left(1^{\text {st }}-3^{\text {rd }}\right.$ quartiles) is given and

Pearson's chi-square test where $\mathrm{n}(\%)$ is given. Post-hoc tests are applied using 2 -sample chi-square test for equality of proportions with continuity correction.

${ }^{a}$ Logarithmic transformation (base 10) was applied. Confidence intervals of geometric mean were computed using 1000 bootstrap samples.

bPatients with liver biopsy were evaluated according to the Ishak score.

c34 patients

d52 patients

e23 patients

We also grouped genotypes according to the presence of the $\mathrm{T}$ allele as $\mathrm{CC}$ versus $\mathrm{CT}+\mathrm{TT}$ and the results were similar. Only viral load $\geq 400,000 \mathrm{IU} / \mathrm{mL} /<400,000 \mathrm{IU} / \mathrm{mL}$ ) was found to be statistically significant between genotypes, as shown in Table $3(\mathrm{p}<0.05)$.

The liver fibrosis score was grouped into mild (0-2), moderate (3-4) and severe (5-6) and the necroinflammation score was grouped as mild (0-6), moderate (7-12) and severe (1318). There was no significant difference between the CC, CT and TT genotypes in the mild, moderate and severe groups for fibrosis and necroinflammation distributions $(\mathrm{p}=0.058$ and $\mathrm{p}=0.791$, respectively) (Figure 2 ). There was no significant difference between IL28B genotypes in terms of mean age $(p=0.738)$, gender distribution $(p=0.573)$, mean BMI $(\mathrm{p}=0.476)$, geometric mean viral load $(\mathrm{p}=0.526)$, genotype $1 \mathrm{~b}$ or genotype 4 distributions $(\mathrm{p}=0.721)$ and median ALT level $(\mathrm{p}=0.210)$ (Table 3).

\section{DISCUSSION}

Chronic-HCV infection is a significant problem in Turkey. Although the Türkiye Hepatitis Prevalence (TURKHEP) study reported a nationwide seroprevalence of $1 \%$, some regions have results as high as $3.1 \%(25,26)$. Prevalence increases after the age of 50. Yildirim et al. (27) reported a prevalence of $4.2 \%$ in $50-59$ year-olds, $3.4 \%$ in $60-69$ year-olds, and $7.1 \%$ 70-79 year-olds. The cost of pegylated-IFN and ribavirin combination used in $\mathrm{CHC}$ treatment is high and it has important side effects. When protease inhibitors used for the treatment of genotype- 1 infected patients is considered, it is clear that the cost and frequency of side effects are much higher. In Turkey, the most common HCV genotype is genotype 1, although genotype 4 is seen more frequently in our center and in our neighborhood, possibly due to immigration (8). Both genotypes belong to the group in which permanent virologi- 


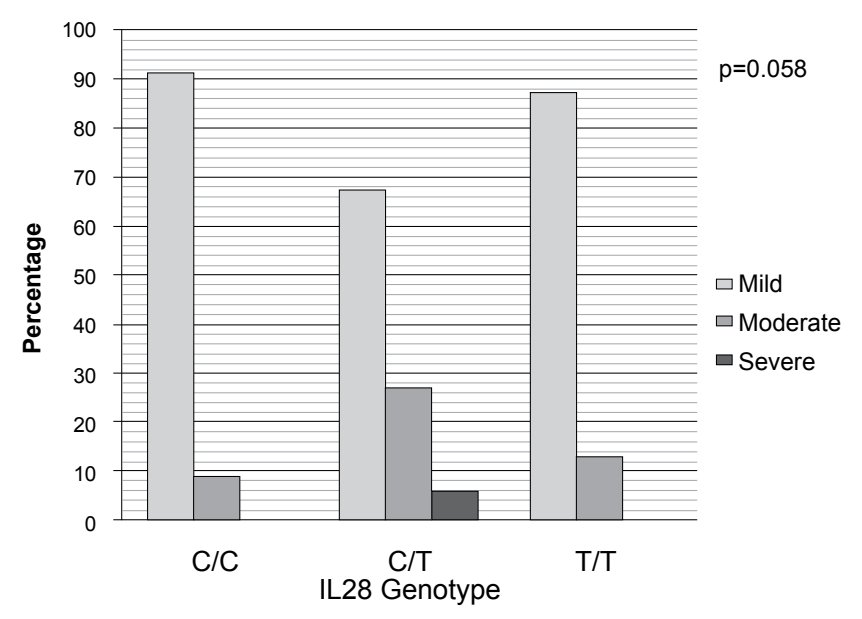

FIG. 2. The relationship between fibrosis score and IL28B rs 12979860 $\mathrm{C} / \mathrm{T}$ polymorphism in patients with chronic $\mathrm{HCV}$ infection

cal response to the drugs used in $\mathrm{CHC}$ is low. For these reasons, before beginning treatment, it is important to predict the response of the patient. In the studies conducted in Turkey, one-third of CHC cases were of the IL28B rs 12979860 CC genotype and almost half were of the IL28B rs8099917 TT genotype (28); no comprehensive studies have been conducted in healthy controls.

Genome Wide Association Studies have mapped different phenotypes or characteristics for thousands of SNPs on all chromosomes (29). GWAS results have indicated that the IL28B rs12979860 (C>T) polymorphism plays an important role in the response for $\mathrm{CHC}$ to the treatment and spontaneous clearance of the virus $(13,14,17,18,30)$. While spontaneous viral clearance occurs only in $15-50 \%$ of HCV-infected patients, chronic infection develops in the majority (31). In a study performed in African or European populations, HCV spontaneous clearance was three-fold higher in patients with the IL28B rs12979860 CC genotype compared to those with the CT and TT genotypes (14). In a study performed in Egypt, the incidence of the CC genotype (48\%) was higher than that of the CT (38\%) and TT (14\%) genotypes in healthy control subjects (31). Furthermore, in these subjects, the $\mathrm{C}: \mathrm{T}$ allele ratio was $67: 33$, indicating that the IL28B CC genotype protects against chronic infection progression by spontaneous clearance during the acute phase (32). In another study performed in Brazil, Conde et al. (33) found no differences between CHC patients and the control group for genotype and allele proportions of IL28B rs12979860 (C>T). They found a tendency $(\mathrm{p}=0.0813)$ towards a higher frequency of allele $\mathrm{T}$ in the group of patients according to the controls, but no significant difference in the genotypic frequency $(\mathrm{p}=0.1865)$ was found between the two groups. In other studies, the CC genotype played a major role in viral clearance caused by treatment
$(34,35)$. In our study, $44.6 \%$ of the cases in the control group were $\mathrm{CC}, 46.7 \%$ of the cases were $\mathrm{CT}$, and $8.7 \%$ were TT. In the patients with $\mathrm{CHC}$, these percentages were $32.1 \%, 46.3 \%$ and $20.6 \%$, respectively. The incidence of the TT genotype in the patient group was significantly higher than in the control group $(p=0.033)$. Contrary to the findings of El-Awaday et al. (31), this indicates that the TT genotype contributes to chronic HCV infection by leading to viral persistence. Fabris et al. (35) reported that the TT genotype was seen more frequently in patients with end-stage liver disease than in those with mild chronic hepatitis. In another Egyptian study, there was a significant difference in the distribution of the IL28B rs12979860 (C>T) genotypes between $440 \mathrm{HCV}$ genotype-4 infected patients and 220 healthy control people (36). In the CHC patients, the prevalence of the CC genotype was $30.7 \%$, that of the CT genotype was $49.5 \%$, and that of the TT genotype was $19.8 \%$, while in the control group the prevalence was $43.6 \%, 42.3 \%$ and $14.1 \%$, respectively. It has been emphasized that there is a significant difference between patient and healthy control groups in genotype prevalence. In this study, the frequency of the $\mathrm{T}$ allele was $44.5 \%$ in $\mathrm{CHC}$ patients and $35.2 \%$ in the control group. Furthermore, we found that the frequency of the $\mathrm{C}$ allele was significantly higher $(68 \%)$ in the control group than in the $\mathrm{CHC}$ treatment group (56\%), and the frequency of the $\mathrm{T}$ allele was lower $(32 \%)$ in the control group than in the CHC treatment group $(44 \%)(p=0.011)$. These results were similar to those reported in studies in Egypt and Italy $(23,36)$. In another study conducted by Shaker et al. (37) in Egypt, the ratios of the $\mathrm{CC}$ genotype and $\mathrm{C}$ allele frequency in the control group were lower than in our study. In our CHC patients, the frequencies of the $\mathrm{CC}$ genotype and $\mathrm{C}$ allele were lower than those described previously in American and European $\mathrm{HCV}$-infected patients $(14,17,38,39)$. The frequency of CC genotype changed between $38 \%$ (17) and $45 \%$ (38) in $\mathrm{HCV}$ infected patients in Europe. Our findings indicate that the existence of the $\mathrm{T}$ allele contributes to viral persistence and $\mathrm{CHC}$ development, supporting results indicating that antiviral treatment response in $\mathrm{CHC}$ was associated with the IL28B polymorphism $(13,14,17,38,40)$.

In a study performed on 871 Caucasian patients, the CC genotype was found $39 \%$, the CT genotype $49 \%$, and the TT genotype $12 \%$ of patients with HCV infection (41). In a Romanian study, these rates were $24.3 \%, 62.6 \%$ and $13.1 \%$, respectively (19); these two studies gave results that are similar to those of our study in which the CT genotype was the most prevalent (46.3\%). Moreover, when the characteristics of the patients with $\mathrm{CHC}$ were evaluated based on the IL28B genotype subgroups, the frequency of patients with viral load $\geq 400,000 \mathrm{IU} / \mathrm{mL}$ was highest in the CT group $(\mathrm{p}=0.021)$, while no differences were found among the groups in terms 
of baseline mean HCV RNA levels. In addition, there were no significant differences in mean age, gender distribution, BMI, genotype distributions, ALT level and median liver necroinflammation among the IL28B subgroups. Montes-Cano et al. (39) reported that, in $284 \mathrm{CHC}$ patients, there was no significant difference between patients in the $\mathrm{CC}$ and $\mathrm{CT}+\mathrm{TT}$ groups with regard to viral load or in gender distribution and infection age; however, the ALT level was higher in the CC group ( $\mathrm{p}=0.006$ ). Sporae et al. (19) determined that baseline viral load was significantly lower in the TT group according to other genotypes and the frequency of patients with viral load $>600,000 \mathrm{IU} / \mathrm{mL}$ was the highest for the CC genotype, at $80.8 \%$. In the same study, no significant difference was seen in terms of mean age, gender distribution, BMI and fibrosis score among the IL28B subgroups. The reason of different viral load frequencies in IL28B subgroups according to other studies can be explained with the presence of factors which is effect viral load such as viral genotype, age, race, gender and route of transmission of infection.

In our study, $90.4 \%$ of the patients had genotype $1 \mathrm{~b}$ infection and the frequency of genotype 4 infection was low. The liver fibrosis distribution was not found to be significantly significant between groups. However, the fibrosis severity seems higher in patients with the CT genotype and the $p$ value was close to 0.05 . This finding may become statistically significant with an increase in sample size $(\mathrm{p}=0.058)$. There was no difference in necroinflammation among the groups $(\mathrm{p}=0.791)$. In the study by Falleti et al. (23) the frequency of genotype 1 infection was $28.1 \%$, the frequency of genotype 2 was $38.2 \%$, the frequency of genotype 3 was $42.3 \%$, and the frequency of genotype $4-5$ was $36.6 \%$, for the CC group. In the same study, the necroinflammation score in the CC group was significantly higher than in the group with $\mathrm{CT}+\mathrm{TT}$ genotype based on the Ishak scoring system. The number of patients with severe hepatitis was higher in group with TT genotype, while the number of patients with mild hepatitis was higher in the group with $\mathrm{CC}$ genotype. In the study by Montes-Cano et al. (39) in the group with the CC genotype, the rate of $\mathrm{HCV}$ infection was $39.1 \%$ for genotype 1 and $66.7 \%$ for the other genotypes. Based on liver biopsy, a fibrosis score of mild was seen in $46.5 \%$ and a score of moderate seen in $43.2 \%$ of patients with the $\mathrm{CC}$ genotypes. In the $\mathrm{CC}+\mathrm{CT}$ group, a fibrosis score of mild was seen in $53.5 \%$ and a score of moderate was seen in $56.8 \%$ of patients. In our study, because of the small number of patients and the fact that most of these had mild liver disease (78.9\%), there may be some misinterpretation of the results. In conclusion, in patients with chronic HCV genotype- $1 \mathrm{~b}$ and 4 infections, the IL28B rs12979860 (C>T) gene polymorphism TT genotype and T allele frequency was higher than in healthy control subjects. Our findings suggest that the
TT genotype might be effective in the progression of $\mathrm{HCV}$ infection. These results can aid clinicians in using antiviral treatment decisions. Further comprehensive studies should examine the effects of the IL28B genotype subgroups on the prognosis of disease and the response to treatment.

Ethics Committee Approval: Ethics committee approval was received for this study from the Ethics Committee for Clinical Re$\operatorname{search}(2013 / 188)$.

Informed Consent: Written informed consent was obtained from patients who participated in this study.

Peer-review: Externally peer-reviewed.

Author contributions: Concept - B.A., S.T., H.C.; Design - S.T., B.A., O.Y.; Supervision - B.A., S.T.; Resource S.T.; Materials - S.T., K.K., O.Y.; Data Collection \&/or Processing - S.T., K.K.; Analysis \&/or Interpretation - G.Z., B.A.; Literature Search - S.T., B.A.; Writing - B.A., S.T.; Critical Reviews - B.A., S.T.

Acknowledgements: The autors thank to Betül-Ziya Eren Genome and Stem Cell Center.

Conflict of Interest: No conflict of interest was declared by the authors.

Financial Disclosure: The authors declared that this study has received no financial support.

\section{REFERENCES}

1. Aygen B. Hepatitis C. Turkiye Klinikleri J Int Med Sci 2006;2:2133.

2. Aygen B. Kronik hepatit C'de tedavi ve izlem: In: Köksal İ, Leblebicioğlu H, editors. Kronik Hepatitlerin Tanı ve Tedavisinde Güncel Yaklaşımlar. 1st ed. Ankara: Bilimsel Tıp Yayınevi; 2009;223-33.

3. Bozkurt I, Aygen B, Gökahmetoglu S, Yildiz O. Hepatitis C and Occult Hepatitis C Infection among Hemodialysis Patients from Central Anatolia. J Pure Appl Microbiol 2014:8:435-40.

4. Bozkurt I, Aygen B, Gökahmetoglu S, Yildiz O. Frequency and epidemiologic characteristics of hepatitis $\mathrm{C}$ virus infection in patients receiving hemodialysis in our region. Klimik Journal 2012;25:19-23. [CrossRef]

5. Mıstık R, Türkiye'de viral hepatit epidemiyolojisi: yayınların irdelenmesi. In: Tabak F, Balik I, Tekeli E, editors. Viral Hepatit 2007. 1st ed. Ankara: Oban Matbaas1; 2007;9-50.

6. Ökten A. Türkiye'de kronik hepatit, siroz ve hepatosellüler karsinoma etiyolojisi. Güncel Gastroenterol Derg 2003;7:18791.

7. Gökahmetoğlu S, Bozdayı M, Özbakır Ö, Aygen B, Özbal Y, Soyuer I, Yildiz O. Hepatitis C virus genotypes detected in Erciyes University. J Turk Microbiol Soc 2007;37:35-8. 
8. Gökahmetoğlu S, Atalay MA, Kılınç A. Determination of the hepatitis C virus genotypes with "pyrosequencing" method. Erciyes Med J 2011;33:99-102.

9. Aygen B, Yıldız O, Çaylan R, Köksal I, Saltoğlu N, Taşova $\mathrm{Y}$, Leblebicioğlu $\mathrm{H}$, et al. Combination of interferon induction therapy and ribavirin in chronic hepatitis $\mathrm{C}$ patients: results of a multicenter clinical trial. Viral Hepatitis Journal 2004;9:123-9.

10. Yıldız O, Aygen B, Alp E, Gökahmetoğlu S, Soyuer I. Retrospective evaluation of different antiviral treatments for chronic hepatitis C infection. FLORA 2008;13:122-9.

11. Aygen, B, Yıldız O, Bostancı F, Özbakır Ö, Gökahmetoğlu S, Patıroğlu TE. A comparison of interferon-alpha- $2 b$ induction therapy with interferon-alpha- $2 b$ plus ribavirin combination therapy for the treatment of chronic hepatitis C. FLORA 2004;9:189-99.

12. Demiraslan H, Aygen B, Yıldız O, Soyuer I, Gökahmetoğlu S. A comparison of interferon $\alpha$-2a plus ribavirin combination therapy with peginterferon $\alpha$-2a plus ribavirin combination therapy for treatment of chronic hepatitis C. Viral Hepatitis Journal 2008;13:12-22.

13. Rauch A, Kutalik Z, Descombes P, Cai T, Di Iulio J, Mueller $\mathrm{T}$, et al. Genetic variation in IL28B is associated with chronic hepatitis $\mathrm{C}$ and treatment failure: a genome-wide association study. Gastroenterology 2010;138:1338-45. [CrossRef]

14. Thomas DL, Thio CL, Martin MP, Qi Y, Ge D, O'Huigin C, et al. Genetic variation in IL28B and spontaneous clearance of hepatitis C virus. Nature 2009;461:798-801. [CrossRef]

15. Fonseca-Coronado S, Vaughan G, Cruz-Rivera MY, Carpio-Pedroza JC, Ruiz-Tovar K, Ruiz-Pacheco JA, et al. Interleukin-28B genotyping by melt-mismatch amplification mutation assay PCR analysis using single nucleotide polymorphisms rs12979860 and rs8099917, a useful tool for prediction of therapy response in hepatitis C patients. J Clin Microbiol 2011;49:2706-10. [CrossRef]

16. Lagging M, Askarieh G, Negro F, Bibert S, Soderholm J, Westin $\mathrm{J}$, et al. Response prediction in chronic hepatitis $\mathrm{C}$ by assessment of IP-10 and IL28B-related single nucleotide polymorphisms. PLoS One 2011;6:e17232. [CrossRef]

17. Ge D, Fellay J, Thompson AJ, Simon JS, Shianna KV, Urban TJ, et al. Genetic variation in IL28B predicts hepatitis C treatmentinduced viral clearance. Nature 2009;461:399-401. [CrossRef]

18. Grebely J, Petoumenos K, Hellard M, Matthews GV, Suppiah V, Applegate T, et al. Potential role for interleukin-28B genotype in treatment decision-making in recent hepatitis $\mathrm{C}$ virus infection. Hepatology 2010;52:1216-24. [CrossRef]

19. Sporea I, Popescu A, Curescu M, Sirli R, Dan I, Goldis A, et al. The correlation of I128B Genotype with sustained virologic response in Romanian patients with chronic hepatitis C. Hepat Mon 2011;11:975-9. [CrossRef]

20. Ghany MG, Nelson DR, Strader DB, Thomas DL, Seeff LB; American Association for Study of Liver Diseases. An update on treatment of genotype 1 chronic hepatitis C virus infection: 2011 Practice guideline by the American Association for the Study of Liver Diseases. Hepatology 2011;54:1433-44. [CrossRef]

21. Omata M, Kanda T, Yu ML, Yokosuka O, Lim SG, Jafri W, et al. APASL consensus statements and management algorithms for hepatitis C virus infection. Hepatol Int 2012;6:409-35. [CrossRef]
22. Ishak K, Baptisa A, Bianchi L, Callea F, De Groote J, Gudat F, et al. Histological grading and staging of chronic hepatitis. $J$ Hepatol 1995;22:696-9. [CrossRef]

23. Falleti E, Bitetto D, Fabris C, Cussigh A, Fornasiere E, Cmet $\mathrm{S}$, et al. Role of interleukin 28B rs12979860 C/T polymorphism on the histological outcome of chronic hepatitis C: relationship with gender and viral genotype. J Clin Immunol 2011;31:891-9. [CrossRef]

24. El Awady MK, Noha El Din NGB, Tabll A, El Hosary Y, Abdel Aziz AO, El Khayat H, et al. IL28B polymorphism and cytomegalovirus predict response to treatment in Egyptian HCV type 4 patients. World J Gastroenterol 2013;19:290-8. [CrossRef]

25. Tozun N, Ozdogan OC, Cakaloglu Y, İdilman R, Karasu Z, Akarca U, et al. Nationwide prevalence study and risk factors for hepatitis A, B, C and D infections in Turkey. Hepatology 2010;52(Suppl 1):697.

26. Özer B, Seydaoğlu G, Özşahın AK, Demırhındı H. Risk factors for higher anti-HCV positivity in a border city in southern Turkey with unique population characteristics. Turk J Gastroenterol 2012;23:574-9.

27. Yildirim B, Barut S, Bulut Y, Yenişehirli G, Ozdemir M, Cetin I, et al. Seroprevalence of hepatitis B and $\mathrm{C}$ viruses in the province of Tokat in the Black Sea region of Turkey: A population-based study. Turk J Gastroenterol 2009;20:27-30.

28. Simsek H, Alp A, Yilmaz B, Balabana YH, Altun B, Uzun $\mathrm{O}$, et al. The genotype frequencies of IL28B polymorphisms (rs12979860, rs8099917) among Turkish patients with hepatitis C. Eur J Gastroenterol Hepatol 2012;24:1113-6. [CrossRef]

29. Manolio TA. Genomewide association studies and assessment of the risk of disease. $N$ Engl J Med 2010;363:166-76. [CrossRef]

30. Kelly C, Klenerman P, Barnes E. Interferon lambdas: the next cytokine storm. Gut 2011;60:1284-93. [CrossRef]

31. El-Awady MK, Mostafa L, Tabll AA, Abdelhafez TH, El Din NGB, Zayed N, et al. Association of IL28B SNP with progression of Egyptian HCV genotype 4 patients to end stage liver disease. Hepat Mon 2012;12:271-7. [CrossRef]

32. Liao XW, Ling Y, Li XH, Han Y, Zhang SY, Gu LL, et al. Association of genetic variation in IL28B with hepatitis C treatmentinduced viral clearance in the Chinese Han population. Antivir Ther 2011;16:141-7. [CrossRef]

33. da Silva Conde SR, Soares Monteiro JC, Silva Dos Santos BT, Fonseca Filgueiras NK, de Almeida Lins PA, Bonfim Freitas F, et al. SNP rs8099917 in gene IL28B might be associated with risk of chronic infection by HCV but not with response to treatment. Biomed Res Int 2014;2014:748606. [CrossRef]

34. Ruiz-Extremera A, Munoz-Gamez JA, Salmeron-Ruiz MA, de Rueda PM, Quiles-Perez R, Gila-Medina A, Casado J, et al. Genetic variation in interleukin $28 \mathrm{~B}$ with respect to vertical transmission of hepatitis $\mathrm{C}$ virus and spontaneous clearance in HCVinfected children. Hepatology 2011;53:1830-8. [CrossRef]

35. Fabris C, Falleti E, Cussigh A, Bitetto D, Fontanini E, Bignulin S, et al. IL-28B rs12979860 C/T allele distribution in patients with liver cirrhosis: role in the course of chronic viral hepatitis and the development of HCC. J Hepatol 2011;54:716-22. [CrossRef] 
36. Pasha HF, Radwan MI, Hagrass HA, Tantawy EA, Emara MH. Cytokines genes polymorphisms in chronic hepatitis $\mathrm{C}$ : Impact on susceptibility to infection and response to therapy. Cytokine 2013;61:478-84. [CrossRef]

37. Shaker OG, Sadik NAH. Polymorphisms in interleukin-10 and interleukin-28B genes in Egyptian patients with chronic hepatitis C virus genotype 4 and their effect on the response to pegylated interferon/ribavirin-therapy. J Gastroenterol Hepatol 2012;27:1842-9. [CrossRef]

38. McCarthy JJ, Li JH, Thompson A, Suchindran S, Lao XQ, Patel $\mathrm{K}$, et al. Replicated association between an IL28B gene variant and a sustained response to pegylated interferon and ribavirin. Gastroenterology 2010;138:2307-14. [CrossRef]
39. Montes-Cano M, Garcia-Lozano J, Abad-Molina C, RomeroGomez M, Barroso N, Aguilar-Reina J, et al. Interleukin-28B genetic variants and hepatitis virus infection by different viral genotypes. Hepatology 2010;52:33-7. [CrossRef]

40. Suppiah V, Moldovan M, Ahlenstiel G, Berg T, Weltman M, Abate ML, et al. IL28B is associated with response to chronic hepatitis $\mathrm{C}$ interferon-alpha and ribavirin therapy. Nat Genet 2009;41:1100-4. [CrossRef]

41. McHutchison JG. The role of genetic markers in hepatitis $\mathrm{C}$ virus therapy: a major step for individualized care. Liver Int 2011;31(Suppl 1):29-35. [CrossRef] 